\title{
Does the Organizational Commitment Act as a Mediator of the Impact of the Organizational Culture and Compensation on the Performance of Employees?
}

\author{
Joko Sabtohadi \\ Peneliti Muda, Balitbangda Kabupaten Kutai Kartanegara
}

\begin{abstract}
The aim of this study was to examine the impact of organizational culture and compensation on the performance of employees and the indirect impact of organizational culture and compensation on the performance of employees through organizational commitment. Based on the study's goals, this study used a quantitative approach. Primary data collection analysis has been carried out using survey techniques. The study was conducted on 56 respondents who were Balitbangda workers, Kutai Kartanegara Regency. Review of the data used in this analysis using SEM-PLS. The results demonstrated the impact of the organizational culture, the compensation and the organizational commitment to the success of the business.
\end{abstract}

Keywords-Organizational culture; Compensation; Organizational Commitment; Employee Performance

\begin{abstract}
Abstrak
Penelitian ini bertujuan untuk menguji pengaruh budaya organisasi dan kompensasi terhadap kinerja pegawai serta pengaruh tidak langsung budaya organisasi dan kompensasi melalui komitmen organisasi. Sesuai dengan tujuan penelitian, penelitian ini menggunakan pendekatan kuantitatif. Pengumpulan data primer penelitian dilakukan dengan teknik survei. Penelitian dilakukan pada 56 responden yang merupakan pegawai di Balitbangda Kabupaten Kutai Kartanegara. Analisis data pada penelitian ini menggunakan SEM-PLS. Hasil penelitian menunjukkan bahwa adanya pengaruh budaya organisasi, kompensasi, dan komitmen organisasi terhadap kinerja perusahaan. Budaya organisasi dan kompensasi juga berpengaruh terhadap komitmen organisasi. Penelitian ini juga membuktikan bahwa komitmen organisasi merupakan variabel mediasi pengaruh budaya organisasi dan kompensasi terhadap kinerja pegawai. Implikasi teoritis penelitian ini mendukung goal setting theory yang menyatakan bahwa bahwa perilaku kerja dari seorang pegawai dipengaruhi oleh bagaimana seseorang memahami tujuan organisasi dan apa yang diharapkan.
\end{abstract}

Kata kunci- Budaya Organisasi; Kompensasi; Komitmen Organisasi; Kinerja Pegawai

\section{INTRODUCTION}

The business world is entering a new era where competition and uncertainty are challenges that must be faced with the right strategy. Companies are required to face competition by creating advantages over competitors. One of the assets that must always be considered to create a company's competitive advantage is Human Resources (HR). Hatta and Rachbini (2015) explain that HR is a source of competitive advantage for companies because HR has potential that is not easily imitated by competitors. Human resource potential includes intellectual, skills, traits, and individual character.

HR management should not only be carried out by profit-oriented companies but also non-profit organizations, including government agencies. The Regional Research and Development Agency (Balitbangda) of Kutai Kartanegara Regency is one of the government agencies that must also pay attention to human resource 
management. HR management aims to increase the effectiveness of human resources which leads to the formation of an effective work unit. HR can be a source of organizational competitive advantage, so Balitbangda Kutai Kartanegara must carry out HR management which has implications for good employee performance.

The factors that need to be considered related to improving employee performance are organizational culture, compensation, and organizational commitment. Minister of Empowerment of State Apparatus and Bureaucratic Reforms' regulation No. 39 of 2012 states that organizational culture is defined as a collective value system in the organization which is used as a guideline for how employees carry out activities in an effort to achieve the goals of an organization. Furthermore, organizational culture will become a control system that affects how employees interact with their stakeholders. Since it's a control mechanism, companies with a strong organizational culture are considered more able to survive than companies with a weak organizational culture. Some of the empirical evidence, includes Dewi and Hasniaty (2017), Hatta and Rachbini (2018), Safitri (2018), Prasetyo, et al. (2018) proved that the stronger the organizational culture will have implications for the better performance of employees of an organization.

As stated above, compensation is also a factor that needs to be considered when an organization wants to improve the performance of its employees. The management of Balitbangda in Kutai Kartanegara Regency needs to understand and know the needs of its employees. Besides serving the country, fulfilling the necessities of life is also the reason government employee's work. Gupta, et al. (2020) states that compensation is any financial and non-financial benefits that can be awarded to workers to motivate them to be more productive and to recognize the performance of their contribution to forward organizations. Employees will work and try to do better if they feel that their previous performance has received appropriate feedback. Meutia, at al. (2016), Riyadi (2019), and Basalamah, et al. (2019) proved that compensation can improve performance. This means that if there is an increase in compensation received by employees, their performance will improve.

Several previous studies have examined the influence of organizational culture and compensation both directly (Dewi and Hasniaty, 2017; Hatta and Rachbini, 2018; Safitri, 2018) and indirectly (Rosyidah, et al., 2018; Basalamah, et al., 2019) on employee performance. As a research model development, the researcher added the organizational commitment variable as a mediating or intervening variable.

Organizational commitment is defined as a person's relationship with an organization that is able to create an attitude and a sense of belonging to the organizational provisions so that they can collectively be implemented and obeyed. Rosyidah, et al. (2018) and Sungu and Weng (2019) empirically proved that good organizational commitment will improve employee performance. Organizational commitment which is manifested in the form of regulations in the organization will be a driving factor for increasing employee performance in an organization.

Organizational commitment is used to mediate the relationship between organizational culture and employee performance based on research by Rosyidah, et al. (2018). While organizational commitment is used to mediate the relationship between compensation and employee performance based on research by Shanty and Mayangsari (2017). This study develops research by Rosyidah, et al. (2018) and Shanty and Mayangsari (2017). So this study aims to determine the direct effect of compensation and organizational culture on the performance of government employees. The next objective is to determine the indirect effect of organizational culture and compensation on employee performance with organizational commitment as a mediating variable.

\section{LITERATURE REVIEW}

\section{A. Organizational Culture and Employee Performance}

The determining factor for how an organization operates is the organizational culture. The implication of the better organizational culture triggers the better behavior of each individual in the organization (Putranto, 2012). Organizational culture acts as a differentiator or identity of an organization compared to other organizations. This is in line with the opinion of Nikpour (2017) which defines organizational culture as representation of organizational members' collective values, convictions and principles.

Hatta and Rachbini (2015), Indrasari (2017), Nuryasman and Suryaman (2018) empirically proved that there is a linear relationship between organizational culture and employee performance. Warrick (2017) stated that performance and effectiveness of a company can be affected by a culture of organisation. A strong organizational culture will also have an impact on better employee performance. 


\section{B. Compensation and Employee Performance}

One of the company's valuable assets is its employees. This is because employees become planners, implementers and controllers in the organization's efforts to achieve its goals. Compensation as a form of appreciation to employees for their performance and dedication to the progress of the company. Compensation in the form of salaries, bonuses, and other rewards can trigger employee motivation to always work better. Teneh, et al. (2015) stated that giving fair compensation can trigger an increase in employee performance in an organization.

Empirically, several previous studies have proven the influence of compensation on employee performance. Some of these studies include Meutia, et al. (2016), Akram, et al. (2018), Basalamah, et al. (2019), and Nuraeni, et al. (2019). This empirical evidence can imply that the high compensation provided by the organization to its employees will improve employee performance. Compensation is also seen as the amount of all workers' awards given by the company for the services over its employees (Mondy \& Martocchio (2016: 247).

\section{Organizational Culture and Organizational Commitment}

Organizational commitment can be interpreted as a relationship between an employee and his organization that can create an attachment to the rules or values that the organization has set to do and be obeyed collectively. Changing work culture requires a continuous process. Organizational culture can form organizational commitment which is closely related to one's behavior at work.

Organizational culture will form organizational commitment which is closely related to one's behavior in completing a job. Organizational culture in a relatively long period of time will create unwritten rules that are well obeyed by its members. Because organizational commitment can also be in the form of a regulation, including unwritten rules, organizational culture can increase organizational commitment.

Several previous studies such as Mitic, et al. (2016) and Mahayasa, et al. (2018) proved that there is a linear relationship between organizational culture and organizational commitment. That is, the stronger the corporate organizational culture, the higher one's commitment to an organization. This can be proven through the emergence of regulations that created by organizational culture.

\section{Compensation and Organizational Commitment}

Employees in government units have different goals in carrying out their duties. There are those who aim to serve the country and there are those that aim to simply fulfill the necessities of life that are obtained through providing compensation for what has been done. Compensation in the form of salaries, bonuses, and other rewards can trigger employee motivation to always work better as a form of commitment to an organization.

Nikpour (2017) which measures commitment with emotional, continous, and normative indicators is proven to be improved through increased compensation. If the compensation received by the employees is getting better, then this can increase the commitment of the employees to the organization. In accordance with Saifunurmazah (2018) which also proved that compensation has an effect on organizational commitment.

\section{E. Organizational Commitment and Employee Performance}

Employee performance is determined by internal and external factors. Internal factors that can change performance understand the values and goals of the organization which are internalized through organizational commitment. In other words, the more a person understands his position and commitment to the organization, the more it will encourage someone to work better. Employees with a high commitment to their organization will form a well-coordinated team. Conversely, when organizational commitment is low, it will reduce productivity and creativity.

Al Zefeiti \& Mohamad (2017) empirically proved that organizational commitment can affect employee performance. Dewi and Hasniaty (2017) also proved that organizational commitment is the factor that has the greatest influence on employee performance compared to other factors, such as leadership style and organizational culture.

\section{F. The Effect of Organizational Culture on Employee Performance with Organizational Commitment as Mediator}

Organizational culture and organizational commitment are factors that affect organizational performance (Al Zefeiti \& Mohamad, 2017; Hatta and Rachbini, 2015; Indrasari, 2017; Nuryasman and Suryaman, 2018; Dewi and Hasniaty, 2017). Nikpour (2017) indirectly explained that organizational culture will build employee commitment and by increasing organizational commitment, employee performance will also increase. In other 
words, if an organization wants to improve the performance of its employees through an increase in organizational culture, then first the organizational culture must be able to be understood and internalized by the realization of high organizational commitment. So that organizational commitment is able to improve employee performance.

\section{G. The Effect of Compensation on Employee Performance with Organizational Commitment as Mediator}

Goal setting theory states that the work behavior of an employee is influenced by how a person understands the goals of the organization and what the organization expects. Compensation is a tool for employees to work in accordance with organizational goals. Compensation will be able to improve employee performance if the amount of compensation received by employees is able to increase organizational commitment in the form of complying with agreed values and regulations as a shared commitment.

Shanty and Mayangsari (2017) stated that giving fair compensation will have an impact on increasing the organizational commitment of an employee to his institution. Employees who have a high organizational commitment will always strive to achieve organizational goals and are responsible for completing the job properly. Thus, the creation of high organizational commitment will be able to improve employee performance.

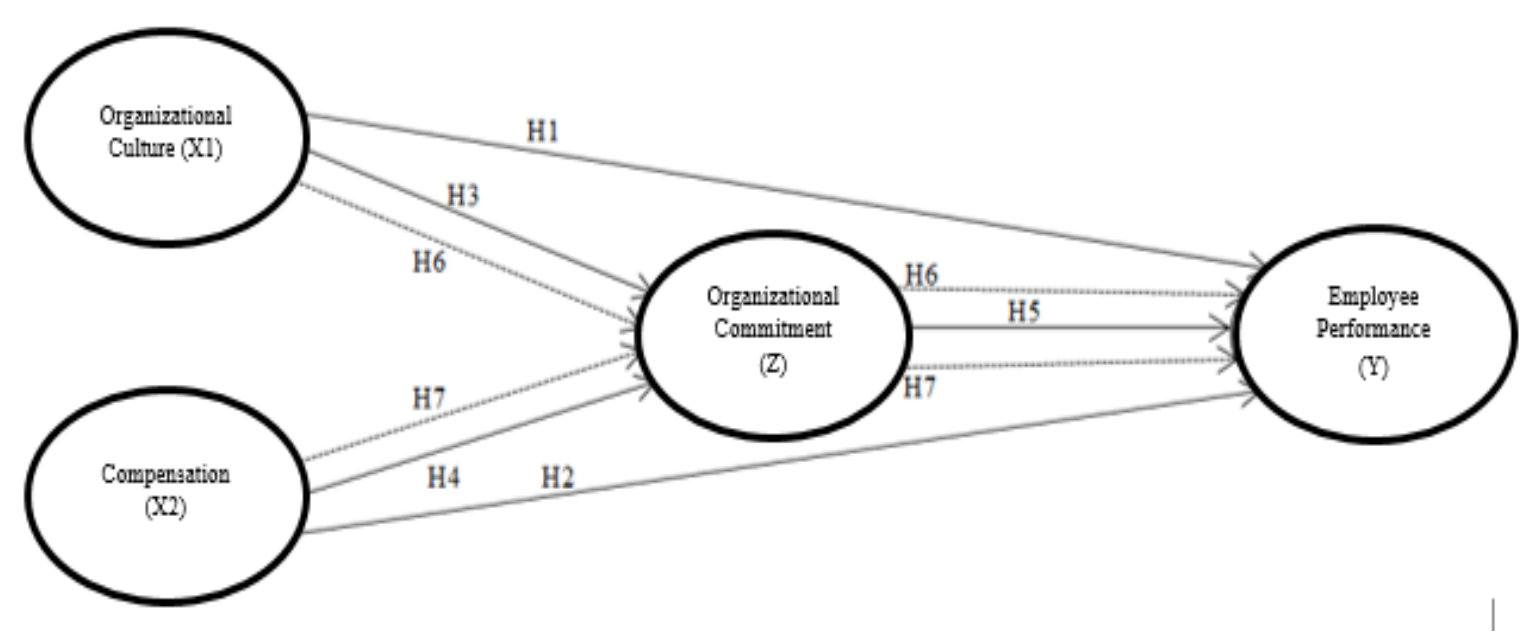

Figure 1. Conceptual Framework

\section{ReSEARCh Methodology}

The quantitative approach is the approach used in this study. This research is classified as explanatory research because it aims to test the hypothesis and develop the research model. This research was conducted at Balitbangda, Kutai Kartanegara Regency. The reason is that based on the achievement of the 2016-2018 budget realization, it has decreased, namely $98.94 \%$ in 2016, $95.53 \%$ in 2017, and $88.32 \%$ in 2018. The sample technique is saturated sampling, namely all employees at Balitbangda, Kutai Kartanegara Regency . Primary data were collected using a survey method by distributing questionnaires. The questionnaires were sent to 108 employees of Balitbangda Kutai Kartanegara. There were 17 employees on leave and 4 employees were carrying out training. 20 questionnaires did not return and 11 questionnaires could not be processed. So that the total sample of the study was 56 respondents $(64 \%)$.

The PLS Structural Equation Model (SEM) with the help of the WarpPLS version 5 application is used as a data analysis tool. Data analysis in the study was carried out in two stages. First, the researcher conducted a descriptive statistical test of the demographics of the respondents and the respondents' answers. Second, testing the outer model by testing the validity and reliability to determine the validity and reliability of each item of the questionnaire statement. Hypothesis testing is done by looking at the path coefficient value and the p-value. Furthermore, the value of $\mathrm{R}^{2}$ is also used in measuring how well the independent variable explains the dependent variable. 


\section{RESUlTS AND DisCUSSION}

\section{A. Description of Respondents}

Research respondents were employees of Balitbangda Kutai Kartanegara. The questionnaire was distributed to all employees of the Regional Research and Development Agency of Kutai Kartanegara Regency. Researchers distributed questionnaires from August to September 2019. Researchers only managed to collect 56 questionnaires. This research has 5 lines so that the minimum total sample is 50 samples. The following is the demographic data of respondents in this study.

Table 2. Respondent Demographic Data

\begin{tabular}{|c|c|c|c|}
\hline & & $\mathbf{n}$ & $\%$ \\
\hline \multirow[t]{3}{*}{ Gender } & Male & 23 & $41,1 \%$ \\
\hline & Female & 33 & $58,9 \%$ \\
\hline & Total & 56 & $100 \%$ \\
\hline \multirow[t]{6}{*}{ Age } & $16-25$ у.о & 1 & $1,8 \%$ \\
\hline & $26-35$ у.о & 14 & $25 \%$ \\
\hline & $36-45$ y.o & 19 & $33,9 \%$ \\
\hline & $46-55$ у.о & 18 & $32,1 \%$ \\
\hline & $>55$ y.o & 4 & $7,1 \%$ \\
\hline & Total & 56 & $100 \%$ \\
\hline \multirow[t]{5}{*}{ Education Level } & SMA & 16 & $28,6 \%$ \\
\hline & $\mathrm{S} 1$ & 31 & $55,4 \%$ \\
\hline & $\mathrm{S} 2$ & 6 & $10,7 \%$ \\
\hline & S3 & 3 & $5,4 \%$ \\
\hline & Total & 56 & $100 \%$ \\
\hline \multirow[t]{5}{*}{ Working period } & $1-10$ years & 15 & $26,8 \%$ \\
\hline & $11-20$ years & 24 & $42,9 \%$ \\
\hline & $21-30$ years & 12 & $21,4 \%$ \\
\hline & $>30$ years & 5 & $8,9 \%$ \\
\hline & Total & 56 & $100 \%$ \\
\hline \multirow[t]{3}{*}{ Employment status } & PNS & 35 & $62,5 \%$ \\
\hline & Non PNS & 21 & $37,5 \%$ \\
\hline & Total & 56 & $100 \%$ \\
\hline
\end{tabular}

\section{B. Inner And Outer Model}

Validity and reliability are tested to test the outer model. Rule of Thumb convergent validity test using a loading value of more than 0.7 . Following are the results of the convergent validity test in this study.

Table 3. Convergent Validity Test Results (Loading Value)

\begin{tabular}{lcc}
\hline Construct & Indicator & Loading Value \\
\hline Organizational Culture (BO) & BO2 & 0,713 \\
& BO3 & 0,780 \\
& BO4 & 0,672 \\
& BO5 & 0,740 \\
Compensation (KOMP) & BO8 & 0,651 \\
& KOMP1 & 0,728 \\
& KOMP2 & 0,829 \\
& KOMP3 & 0,823 \\
& KOMP4 & 0,878 \\
Employee Performance (KIN) & KOMP5 & 0,785 \\
& KOMP6 & 0,867 \\
& KIN1 & 0,733 \\
& KIN2 & 0,881 \\
Organizational Commitment (KO) & KIN3 & 0,818 \\
& KIN4 & 0,709 \\
& KIN6 & 0,579 \\
& KO8 & 0,762 \\
\hline
\end{tabular}




\begin{tabular}{ll}
\hline KO9 & 0,735 \\
KO10 & 0,602 \\
KO11 & 0,869 \\
KO13 & 0,764 \\
KO15 & 0,578 \\
\hline
\end{tabular}

The results of the convergent validity test in table 3 show that all constructs have a loading value>0.7. So that it can be concluded that it passes the convergent validity test. Furthermore, the discriminant validity test can be seen based on the square root of AVE whose value must be greater than the correlation between latent variables.

Table 4.Discriminant Validity Test Results (Square Root AVE)

\begin{tabular}{lc}
\hline \multicolumn{1}{c}{ Construct } & Square Root AVE \\
\hline Organizational Culture (BO) & 0,713 \\
Compensation (KOMP) & 0,820 \\
Employee Performance (KIN) & 0,751 \\
Organizational Commitment (KO) & 0,725 \\
\hline
\end{tabular}

Based on the validity test in table 4, it is known that all research constructs already have the square root AVE> correlation between variables. So it can be concluded that the research construct meets the criteria for the discriminant validity test.

Furthermore, the research construct reliability test was carried out by looking at the Cronbach's alpha and composite reliability values which must be more than 0.7 . The following are the results of the reliability test in this study.

Table 5. Reliability Test Results

\begin{tabular}{lcc}
\hline \multicolumn{1}{c}{ Construct } & Cronbach's Alpha & Composite Reliability \\
\hline Organizational Culture (BO) & 0,756 & 0,837 \\
Compensation (KOMP) & 0,901 & 0,925 \\
Employee Performance (KIN) & 0,800 & 0,864 \\
Organizational Commitment (KO) & 0,814 & 0,867 \\
\hline
\end{tabular}

Based on the results of the reliability test, it appears that all the constructs in this study have Cronbach's alpha and composite reliability values> 0.7. So that the conclusion is that the research construct can be said to be reliable or reliable.

Second, the inner model analysis was carried out to determine the R2 value and to test the hypothesis. The value of R2 shows how much the independent variable can explain the dependent variable. While the path coefficient value and $\mathrm{p}$ value are used to test the hypothesis in this study. The hypothesis is accepted if the $\mathrm{p}$ value <alpha (0.05). Hypothesis testing in this study was carried out in two stages, namely testing the direct effect and indirect effect (Figure 2 and Figure 3).

Based on Figure 3 below, the performance variable shows that the R2 value is 0.36 . This indicates that the independent variables in the form of organizational culture, compensation, and organizational commitment are able to explain the dependent variable in the form of employee performance (KIN) by $36 \%$ while the remaining $64 \%$ is explained by other variables. The R2 value for the organizational commitment variable is 0.12 or $12 \%$. This means that the independent variables in the form of organizational culture and compensation are able to explain the dependent variable in the form of organizational commitment by $12 \%$. 


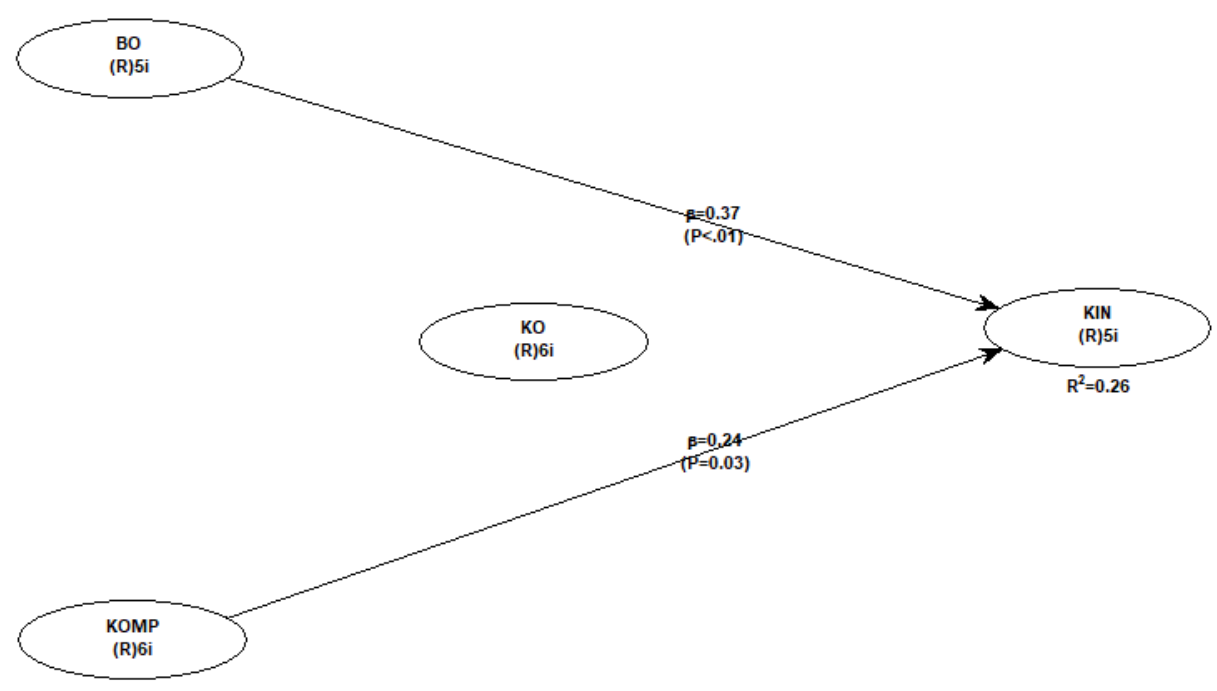

Figure 2. Direct Effect Testing

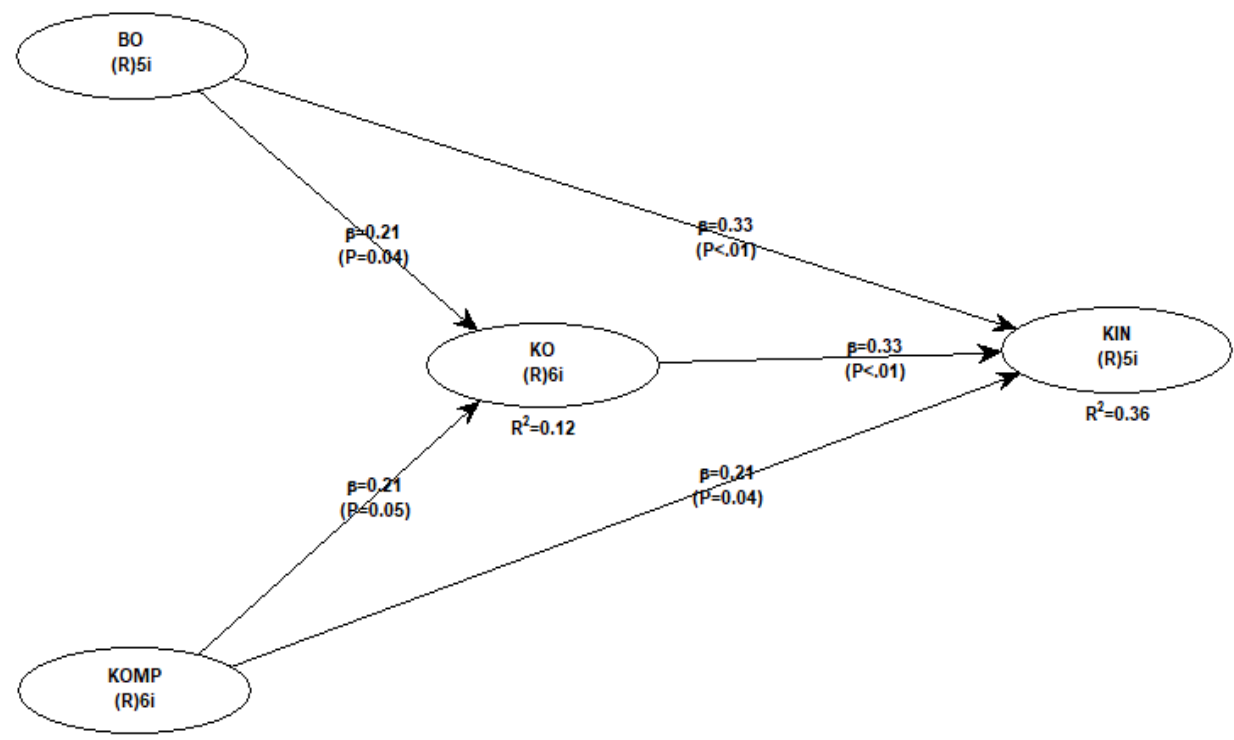

Figure 3. Indirect Effect Testing Results

Based on the results of the inner model testing in Figures 2 and 3, the results of testing the hypothesis of this study can be summarized in table 6 as follows

Table 6. Hypothesis Testing Results

\begin{tabular}{lccll}
\hline & Path Coefficient & P Values & Sig. & Conclusion \\
\hline BO $=>$ KIN & 0,369 & 0,001 & Significant & H1 accepted \\
KOMP => KIN & 0,238 & 0,028 & Significant & H2 accepted \\
BO $=>$ KO & 0,215 & 0,044 & Significant & H3 accepted \\
KOMP => KO & 0,212 & 0,046 & Significant & H4 accepted \\
KO $=>$ KIN & 0,325 & 0,004 & Significant & H5 accepted \\
\hline
\end{tabular}

The first hypothesis about the alleged influence of organizational culture on employee performance is accepted. This is because the path coefficient value is 0.369 with a significance ( $p$ value 0.001 ) $<0.05$. The 
conclusion is that there is a significant influence between organizational culture on employee performance at Balitbangda Kutai Kartanegara Regency.

The second hypothesis of this study is about the alleged influence of compensation on employee performance. The results of hypothesis testing in table 6 show that the path coefficient is 0.238 with a significance below 0.05 (p-value of 0.028 ). So it can be concluded that the second hypothesis is accepted. It is proven that there is an effect of compensation on employee performance.

The third hypothesis of this study states the influence of organizational culture on organizational commitment. Hypothesis testing shows that the path coefficient value is 0.215 with significance below 0.05 , namely a p-value of 0.044 . So it can be concluded that the third hypothesis is accepted.

The fourth hypothesis states that compensation has an effect on organizational commitment. The results show that the path coefficient value is 0.212 with significance below 0.05 , namely the p-value of 0.046 . So it can be concluded that the fourth hypothesis is accepted. It is proven that there is an effect of compensation on organizational commitment.

The fifth hypothesis states that there is an effect of compensation on employee performance. The results of hypothesis testing show that the path coefficient value is 0.325 with significance below 0.05 , which is a p-value of 0.004 . So it can be concluded that the fifth hypothesis is accepted. It is proven that there is a positive and significant effect of organizational commitment on employee performance.

The sixth hypothesis of this study states that there is an indirect influence of organizational culture on employee performance with organizational commitment as a mediator. Based on the results of direct testing (in Figure 2), the results show that there is an influence of organizational culture on employee performance with a path coefficient of 0.369 and a p-value of $<0.001$. Furthermore, testing the indirect effect (in Figure 3 ) proves that there is a significant influence of organizational culture on employee performance. It can also be seen that the path coefficient value has decreased to 0.329 but is still significant (p-value <0.001). In conclusion, the organizational commitment variable is a mediating variable, namely the partial mediation form. This indicates that the variable organizational commitment is not the only mediator in the relationship between organizational culture and employee performance. So that H6 is accepted.

The seventh hypothesis of this study states that there is an indirect effect of compensation on employee performance with organizational commitment as a mediator. Based on the results of direct testing (in Figure 2), it can be seen that there is a compensation effect on employee performance with a path coefficient value of 0.238 and a p-value of 0.028 . While testing the indirect effect (in Figure 3), it can be seen that compensation has an effect on employee performance even though the path coefficient value has decreased to 0.214 but is still significant ( $\mathrm{p}$-value of 0.044). It is concluded that the organizational commitment variable is a mediating variable in the form of partial mediation. This indicates that the variable organizational commitment is not the only one that mediates the relationship between compensation and employee performance. So that $\mathrm{H} 7$ is accepted.

\section{Discussion}

\section{Organizational Culture and Employee Performance}

Employee performance is a form of employee achievement in carrying out work within a certain time according to organizational requirements. This study measures the performance of three aspects, namely the quantity of work results, quality of work and desire. Based on the results of hypothesis testing, it is known that there is an influence of organizational culture on employee performance.

The results of this study confirm the results of research conducted by Safitri (2018) which also proved that companies that want to improve employee performance must pay attention to and improve organizational culture. Dewi and Hasniaty (2017) also proved that increasing organizational culture will have implications for improving employee performance. The results of this study are also in line with Warrick's (2017) opinion that performance and effectiveness of a company can be affected by a culture of organisation. A strong organizational culture will also have an impact on better employee performance. The results of this study indicate that the performance of employees at Balitbangda Kutai Kartanegara Regency is caused by a strong organizational culture. This means, Balitbangda employees of Kutai Kartanegara Regency feel that the driving force for increased employee performance is due to a good organizational culture. This research contradicts the results of research conducted by Prasetyo, et al. (2018) which actually proves that organizational culture is not a determining factor for employee performance. 


\section{Employee Compensation and Performance}

Compensation is a management tool to motivate employees to work according to established standards in order to achieve organizational goals. The second hypothesis of this study states that there is an effect of compensation on company performance. Based on the results of hypothesis testing, it is known that there is a positive and significant relationship between compensation and employee performance.

This research is consistent with the results of research conducted by Riyadi (2018) which also proves that an increase in compensation will result in an increase in employee performance. The better the compensation received by the employee, the better the performance. This is in accordance with the opinion of Teneh, et al. (2015) which states that fair compensation can trigger an increase in employee performance in an organization. The results of this study indicate that the improvement in the performance of Balitbangda staff in Kutai Kartanegara Regency is triggered by the provision of compensation, both financial and non-financial compensation. The results of this study are also in line with research conducted by Meutia, et al. (2016) which proves that there is a positive and significant influence between compensation and employee performance. This indicates that the compensation provided by the company is in accordance with the expectations of employees, so this motivates employees to work better. The results of this study contradict research conducted by Basalamah, et al. (2019) which proves that compensation is not a factor affecting employee performance improvement.

\section{Organizational Culture and Organizational Commitment}

The third hypothesis states that it is assumed that there is an influence of organizational culture on employee performance. The results of hypothesis testing prove that organizational commitment is determined by organizational culture. Organizational culture in a certain period of time will be able to form organizational commitment which is closely related to individual behavior in completing each job.

This study confirms the results of research conducted by Nikpour (2017) which also proved that a strong organizational culture leads to high organizational commitment. Mahayasa, et al. (2018) also proved the results of the same analysis that there was a positive influence between organizational culture and organizational commitment. The values adopted by individuals into organizational culture will bring good changes to organizational commitment.

Empirically, this research proves that in the Balitbangda of Kutai Kartanegara Regency, the organizational culture is able to encourage organizational commitment in order to achieve common goals or ideals. Organizational culture at Balitbangda Kutai Kartanegara Regency can create commitments in the form of written and unwritten rules. A strong organizational commitment is also indicated by looking at the turnover rate in an organization. This is because the organizational culture that is rooted in each individual will make a commitment to always be in the organization, including in the Balitbangda Kutai Kertanegara.

\section{Compensation and Organizational Commitment}

Compensation is a feedback given by the organization on what employees have done to achieve organizational goals. Compensation is an organizational tool to influence and maintain employee commitment to the organization. The results of this study indicate the effect of compensation on organizational commitment at Balitbangda Kutai Kartanegara Regency.

The results of this study are in line with the research conducted by Saifunurmazah (2018) which prove that compensation is a determining factor for organizational commitment. This means that the stronger the culture adopted by the members of the organization will encourage the creation of organizational commitment from each member of the organization. Compensation is a description of the work performed by an employee. Compensation that is given fairly will bring increased organizational commitment.

Empirically, this research proves that employees at Balitbangda Kutai Kartanegara Regency feel that organizational commitment is influenced by the compensation received by employees. In this case, compensation is seen as a determining factor of organizational commitment. The more appropriate the compensation received by the Balitbangda staff of Kutai Kartanegara Regency, the more appropriate it will have an impact on strengthening the organizational commitment of each employee. Compensation in the form of salaries, bonuses, and other rewards can trigger employee motivation to always work better as a form of commitment to an organization. Goal setting theory states that the work behavior of an employee is influenced by how a person understands the goals of the organization and what the organization expects. Besides creating services to the community, compensation is another goal of an organization that seeks to improve the welfare of its employees. 


\section{Effect of Organizational Commitment on Employee Performance}

Organizations that have a strong commitment will encourage employees to try to work better in line with shared commitments. The better the organizational commitment to the Balitbangda of Kutai Kartanegara Regency, the better the employee's performance will be.

The results of this study confirm the results of research by Rosyidah, et al. (2017) and Nikpour (2017). That is, if an organization wants to improve the performance of its employees, then the organizational commitment must be increased. Dewi and Hasniaty (2017) also prove the effect of organizational commitment on employee performance. Even of the three variables studied (organizational commitment, leadership style, organizational culture), organizational commitment is the most dominant determinant of employee performance. This indicates that organizational commitment contributes the most to the realization of employee performance. The results of this study contradict the results of research by Rosyidah, et al. (2018), Putro (2018), and Basalamah, et al. (2019) which proves that organizational commitment is not a determining factor for employee performance.

Empirically, this research proves that according to Balitbangda employees of Kutai Kartanegara Regency, employee performance is influenced by organizational commitment. The stronger organizational commitment at Balitbangda Kutai Kartanegara Regency will trigger employee performance improvements. In other words, the management of Balitbangda of Kutai Kartanegara Regency has succeeded in creating organizational commitment that is able to improve the performance of its employees.

\section{Organizational Culture, Employee Performance, and Organizational Commitment}

Organizational culture is defined as a form of internalization of the values held by each employee which forms certain written and unwritten rules which are adhered to by every member of the organization. The results of this study indicate that organizational culture directly affects employee performance. In addition, indirectly, the influence of organizational culture affects employee performance which is mediated by organizational commitment.

The results of this study confirm the results of research conducted by Nikpour (2017) proved that organizational culture will have implications for increasing employee commitment. Through this organizational commitment, organizational culture is able to influence employee performance. Empirically, this research shows that according to employees at Balitbangda Kutai Kartanegara Regency, organizational culture can increase organizational commitment and in turn will improve employee performance. Organizational culture within a certain period of time will form organizational commitment in the form of written and unwritten rules which are obeyed by all employees. A strong organizational commitment is then able to change the behavior of employees to always work as well as possible so that the performance of employees at Balitbangda in Kutai Kartanegara Regency increases. The partial mediation form of the role of organizational commitment as a mediator of organizational culture on employee performance indicates that there are other variables that are thought to mediate organizational culture on employee performance.

\section{Compensation, Employee Performance, and Organizational Commitment}

Compensation is one of the reasons a person does his job as well as possible. Employees assume that if the performance is good it will affect the feedback received. Therefore, compensation is often the goal of someone to work well. This is in accordance with the Goal Setting Theory which states that the work behavior of an employee is influenced by how a person understands the goals of the organization and what the organization expects. The results of this study prove that compensation has an effect on employee performance through organizational commitment.

The results of this study are in line with the opinion of Shanty and Mayangsari (2017) which states that fair compensation will have an effect on increasing the organizational commitment of an employee to the organization. Employees who have a high organizational commitment will always strive to achieve organizational goals and are responsible for completing every job. Thus, the creation of high organizational commitment will be able to improve employee performance. Empirically, this research proves that the compensation received by Balitbangda employees of Kutai Kartanegara Regency is able to increase the organizational commitment of its employees. Since employee compensation can increase organizational commitment, strong organizational commitment will ultimately influence employees to work according to the commonly established standards and goals. The results of this study confirm the goal setting theory. This means that compensation is one of the goals of Balitbangda employees of Kutai Kartanegara Regency. 


\section{CONCLUSION}

Human resource management is one of the sources of competitive advantage in an organization. Improving employee performance in an organization needs to be considered by implementing several strategies and paying attention to several determining factors. Employee performance can be influenced by several factors, namely organizational culture, compensation, and organizational commitment.

The organizational culture that distinguishes one organization from another is a determining factor for employee performance. In other words, organizational culture affects employee performance. Apart from organizational culture, compensation and company commitment also have a positive effect on employee performance. This means that the better the compensation received by employees and the higher the organizational commitment that employees hold will have an impact on improving organizational performance. The indirect test in this study shows that the influence of organizational culture and compensation is mediated by organizational commitment. That is, improving employee performance through improving organizational culture and compensation must first be able to form organizational commitment which in turn will improve employee performance.

This study proves organizational commitment as a partial mediation of the relationship between organizational culture and compensation for organizational performance. Because it still plays a role as partial mediation, further research can add other mediating variables such as work motivation (Meutia, et al., 2018; Jufrizen, 2015) and work stress (Riyadi, 2019). In addition, the R2 value of the performance variable is still $36 \%$, which indicates that $64 \%$ of other variables are able to explain employee performance that have not been included in the research model. So, further research can add variables that explain employee performance, such as job satisfaction, work environment, and individual characteristics (Riyadi, 2019).

\section{REFERENCES}

Abdillah, W., \& Jogiyanto, H. M. (2015). Partial Least Square (PLS) Alternatif Structural Equation Modeling (SEM) dalam Penelitian Bisnis. Yogyakarta: ANDI.

Akram, M. S., Khan, A. S., Shah, D. S. M. A., \& Khan, D. J. A. (2018). The Effect of Training and Compensation on Job Performance; Accessing the Moderating Role of Motivation: A Case Study of Public Sector of Pakistan. Journal of Business and Tourism, 4(2), 39-51.

Al Zefeiti, S. M. B., \& Mohamad, N. A. (2017). The Influence of organizational commitment on Omani public employees' work performance. International Review of Management and Marketing, 7(2), 151-160.

Basalamah, I., Ramli, M., Sinring, B., \& Alam, R. (2019). Effect of Commitment, Compensation, and Leadership on Employee Performance and Sharia Engagement as Variabel Intervening. International Journal of Accounting \& Finance in Asia Pasific, 2(1), 1-17.

Dewi, A. R. S., \& Hasniaty. (2017). Pengaruh Gaya Kepemimpinan, Budaya Organisasi, dan Komitmen Organisasi terhadap Kinerja Pegawai Dinas Pertanian Kabupaten Mamuju. Jurnal Bisnis, Manajemen, dan Informatika, 2(2), 92-102.

Gupta, S. K., Reznik, N. P., Esra, S., Sayonara, F. T., \& Abrham, F. (2020). Analysis of the Effect of Compensation on Twitter Based on Job Satisfaction on Sustainable Development of Employees Using Data Mining Methods. Talent Development \& Excellence. 12(3),3289 - 3314.

Hatta, I. H., \& Rachbini, W. (2018). Budaya Organisasi, Insentif, Kepuasan Kerja, dan Kinerja Karyawan Pada PT Avrist Assurance. Jurnal Manajemen, 19(1), 74-84.

Indrasarim, M. (2017). The Effect of Organizational Culture, Environmental Work, Leadership Style on The Job Satisfaction and Its Impact on The Performance of Teaching in State Community Academy Bojonegoro. SINERGI, 7(2), 58-73.

Juliningrum, E., dan Sudiro, A. (2017). Pengaruh Kompensasi dan Lingkungan Kerja Terhadap Motivasi Pegawai dalam Memberikan Pelayanan Prima Pada Dinas Pendapatan. Pengelolaan Keuangan, dan Aset Daerah Kabupaten Soppeng. Jurnal Mirai Management, 2(1), 24-29.

Jufrizen. (2015). Pengaruh Kompensasi dan Pengembangan Karir Terhadap Komitmen Organisasi dengan Kepuasan Kerja Sebagai Variabel Intervening Pada PT. Perkebunan Nusantara III (Persero) Medan. Jurnal Ilmiah Manajemen dan Bisnis, 15(1), 37-47.

Mahayasa, I. G. A., Sintaasih, D. K., \& Putra, M. S. (2018). Pengaruh Kepuasan Kerja dan Budaya Organisasi Terhadap Komitmen Organisasional dan Organizational behavior Perawat. Matrik: Jurnal Manajemen, Strategi Bisnis dan Kewirausahaan, 12(1), 71-86. 
Meutia, Sari, I., \& Ismail, T. (2016). Pengaruh Kompensasi dan Kompetensi dengan Motivasi Sebagai Intervening dalam Meningkatkan Kinerja. Jurnal Manajemen, 20(3), 353-369.

Mitić, S., Vukonjanski, J., Terek, E., Gligorović, B., \& Zorić, K. (2016). Organizational culture and organizational commitment: Serbian case. Journal of engineering management and competitiveness (JEMC), 6(1), 21-27.

Mondy, R. Wayne dan Martocchio, Joseph J. (2016). Human Resource Management, Fourteenth Edition, Global Edition. Pearson Education Limited

Nikpour, A. (2017). The impact of organizational culture on organizational performance: The mediating role of employee's organizational commitment. International Journal of Organizational Leadership, 6, 65-72.

Nuraeni, S., Mattalatta, M., \& Syukur, A. (2019). Pengaruh Gaya Kepemimpinan Dan Kompensasi Terhadap Kinerja Pegawai Melalui Motivasi Kerja Di Kecamatan Bantaeng Kabupaten Bantaeng. YUME: Journal of Management, 2(1), 1-14.

Nuryasman, M. N., \& Suryaman, E. A. (2018). The Influence of Organizational Culture and Work Motivation Toward Employee Performance (Case Study on Employees of PT Inoac Polytechno Indonesia). Jurnal Manajemen, 22(1), 74-90.

Peraturan Menteri Pendayagunaan Aparatur Negara dan Reformasi Birokrasi Republik Indonesia Nomor 39 Tahun 2012 Tentang Pedoman Pengembangan Budaya Kerja.

Prasetyo, A. Y., Sularso, R. A., \& Handriyono, H. (2018). Pengaruh Kepercayaan Pada Pimpinan, Mutasi Dan Budaya Organisasi Terhadap Motivasi Kerja Dan Kinerja Pegawai Di Badan Pendapatan Daerah Kabupaten Jember. BISMA, 12(2), 182-190.

Putranto, A. E., (2012). Pengaruh Budaya Organisasi Terhadap Efektivitas Kerja Pegawai Kantor Bagian Pemerintahan Kabupaten Tulungagung. Jurnal OTONOMI, 12(1).

Putro, P. U. W. (2018). Etika Kerja Islam, Komitmen Organisasi, Sikap pada Perubahan Organisasi terhadap Kinerja. Jurnal Manajemen Indonesia, 18(2), 116-125.

Riyadi, S. (2019). The Influence of Job Satisfaction, Work Environment, Individual Characteristics and Compensation toward Job Stress and Employee Performance. International Review of Management and Marketing, 9(3), 93-99.

Rosyidah, E., Fadah, I., \& Tobing, D. S. K. (2018). Pengaruh Kepuasan Kerja dan Budaya Organisasi Terhadap Kinerja Pegawai Melalui Komitmen Organisasi di Unit-Unit Pelayanan Publik Kabupaten Jember. Relasi: Jurnal Ekonomi, 14(1), 1-16.

Safitri, R. P. (2018). Pengaruh Budaya Perusahaan Terhadap Motivasi Kerja Dan Dampaknya Pada Kinerja Karyawan. Journal of Management Review, 2(2), 198-202.

Saifunurmazah, D., Solovida, G. T., \& Hidajat, T. (2018). Pengaruh Gaya Kepemimpinan, Kompensasi dan MOtivasi Terhadap Komitmen Organisasional (Studi pada PT Bank Mandiri Syariah Tbk Semarang. Jurnal Magisma, 6(2), 13-19.

Shanty, D., \& Mayangsari, S. (2017). Analisis Pengaruh Kompensasi, Motivasi, Lingkungan Kerja Terhadap Kinerja Karyawan Dengan Komitmen Organisasional Sebagai Variabel Intervening. Jurnal Informasi, Perpajakan, Akuntansi Dan Keuangan Publik, 12(2), 103-120.

Sungu, L. J., Weng, Q., \& Xu, X. (2019). Organizational commitment and job performance: Examining the moderating roles of occupational commitment and transformational leadership. International Journal of Selection and Assessment, 27(3), 280-290.

Teneh, F. C. M., Tewal, B., \& Tawas H. N. (2015). Analisis Peran Kepemimpinan, Keadilan Kompensasi, dan Kepuasan Kerja Terhadap Komitmen Organisasi dan Kinerja Pegawai Dinas Koperasi dan UMKM Provinsi Sulawesi Utara. Jurnal EMBA, 3(4), 55-67.

Warrick, D. D. (2017). What leaders need to know about organizational culture. Business Horizons, 60(3), 395404. 